\title{
Use of Learning Strategies and their Effects on English Language Learning of Thai Adult Learners
}

\author{
KASMA SUWANARAK \\ Graduate School of Language and Communication \\ National Institute of Development Administration (NIDA) \\ kasma.suwanarak@gmail.com
}

\begin{abstract}
This research aims to explore what a repertoire of learning strategies of Thai EFL students are, how they transfer those strategies to English learning, and to what degree the strategies are beneficial for their English learning achievement. The effects of strategy instruction on the students' awareness of the language learning strategies are highlighted. Differences of strategy types and frequency of strategy use in different groups of low and high strategy users as well as high and low achievers of English language learning are identified. The study employs a mixed-methods research methodology. The quantitative data are collected through a 40-item general learning strategies questionnaire. The participants are 219 undergraduate students enrolling for a foundation English course. The qualitative data are derived from 32 student participants voluntarily taking part in semistructured interviews. The quantitative findings show that there is no significant difference on the strategies used for general learning and English learning. The students transfer their repertoire of learning strategies as a primary learning tool to contend with their English learning. There is positive correlation between the learning strategy use and the English learning achievement. The strategy instruction does not show a significant increase in strategy use. High and low achieving students use similar learning strategies; nevertheless, the frequency of learning strategy use and by what means they use the strategy signifies different types of language learners. The qualitative findings are complemented and help extend the quantitative data. Implications of the study concerning pedagogy in particular suggest a new perspective for the EFL Thai teachers in implementing suitable learning strategies for the students to learn more successfully.
\end{abstract}

Keywords: learning strategies; English learning strategies; transfer of learning strategies; strategy instruction; English learning achievement

\section{INTRODUCTION}

Currently a focus on teaching methods has been changed to learning methods, and learning strategies typify the methods or the strategic knowledge each learner holds with the aim of handling information to achieve learning goals. To identify mechanisms, actions, and behaviors that could help learners to attain learning achievement, cognitive psychology has come into play as it concerns effective ways of processing information and the link between learning strategies and learners' mental processes. For ages, researchers and teachers have tried different methods to facilitate learners to attain learning goals. However, whether or not learners will be successful, it also depends on to what extent the learners take a responsible and proactive role that allows them to be consistent and persist longer in learning (Cohen, 2011).

One of the methods used for achieving goals is the learning strategies which are processes, behaviors, techniques, or actions that learners use to deal with learning tasks and reach learning goals (Oxford, 2011). Wong and Nunan (2011) posit that the selection of applicable strategies will produce a repertoire of learning strategies which is a set of strategies individual learners have and acquire through experience and time to support their learning achievement. Learners have a set of general learning strategies that they use in their areas of expertise and which are useful for any learning conditions. Accordingly, learners may transfer the strategies to new learning contexts (James, 2010). 
Research in language learning strategies (e.g., Castillo \& Cordora, 2014; Chamot, 2004; Cohen, 2011; Hung, 2019; Jantawong et al., 2018; Liu, 2010; Mochizuki, 2016; Oxford, 2003) postulates that strategies play an important role not only in language achievement but also in the motivation which is likely to be increased when learners perceive the attainment of good results. However, previous research has not determined where the strategies that learners use in English language learning come from, or how strategies are developed in language learners. Students in higher education, in particular, have much more experience of English language learning and using various types of learning strategies which they consider either useful or not useful resources for their learning achievement. In turn, they may keep on using those learning strategies in the process of language learning.

In this regard, research on the transfer of general learning strategies to language learning and the effect they have on language learning is worth exploring for different reasons. Identifying learners who do not have a developed strategy repertoire brings about an understanding of how strategic learners will be in language learning. As a result, teachers can help equip learners with appropriate learning strategies.

Additionally, knowing what learning strategies are used by a particular group of learners and what the impact of using the strategies the learners have can be useful information for teachers and/or strategy instructors in choosing and emphasising on types of strategies that leaners need. Moreover, making learners aware of their learning strategies used regularly may help them recognise possible benefits that the strategies can bring to their learning. Accordingly, learners themselves can discover their learning strategies, rearrange their strategy repertoire, look for new strategies, and develop new ones, and finally, contribute to their language learning achievement.

The findings of this study would be of interest to scholars in learning strategies and teachers of English language learning at the beginning level. This study sets out to identify general learning strategies that the beginning learners use when they start new lessons. In this regard, this study contributes to the existing body of literature in the filed by continuing lines of research on learning strategies along existing ones but expanding it to the strategy transfer across contexts. From this perspective, the study calls attention to a new insight into language learning by examining it from the angle of the general learning strategies transferred to and used in English language learning.

Although much is known about learning strategies and consequences they have on learning achievement, this study contributes to identifying general learning strategies as predictors of language learning achievement. The findings are beneficial for enhancing the general learning strategies to improve English language achievement. The results will also provide necessary information about strategy instruction and the advantages of teaching strategies to learners at beginning levels. Moreover, the study would help depict the way in which both high and low achieving students use learning strategies, as well as their language learning performance. Teachers and authorities of the university where this study was carried out would find better ways to support their students to step forward to upper levels by supplying them with appropriate learning strategies.

Accordingly, five research questions were developed as follows:

1) How do the students use learning strategies?;

2) How do the students transfer their learning strategies to English learning strategies?;

3) To what extent does the use of learning strategies relate to the prediction of the students' English learning achievement?; 
4) How does the strategy instruction play a role in the students' use of English learning strategies?; and

5) To what extent do the students' learning achievement relate to the use of learning strategies and English learning strategies?

\section{LITERATURE REVIEW}

\section{STRATEGIES USED FOR GENERAL LEARNING AND LANGUAGE LEARNING}

Learning strategies are psychological procedures of individual learners for achieving cognitive goals. They are thoughts, behaviours, beliefs or emotions which facilitate learners' acquisition and understanding of new knowledge and skills (Weinstein \& Palmer, 2002). Cohen and Macaro (2007) underline that strategies are consciously selected; learners decide when to use strategies based on their belief that the strategies will be effective for a particular task and learning achievement. Nevertheless, according to Blasiman et al. (2017), it is not clear that on what basis learners choose certain strategies, how they use the strategies, and why they have a preference over others even though a large amount of research has identified variables affecting learners' choices of learning strategies. In response to this, it can be explained that learners choose strategies from their repertoire of strategies with a belief that the chosen ones will be helpful for performing learning tasks and achieving goals (Dörnyei, 2005).

Oxford (1996) defines language learning strategies as particular actions, behaviors, steps or techniques which help facilitate language learning to be more autonomous, effective, and transferrable to new learning situations. Likewise, Griffiths (2013) describes language learning strategies as careful thoughts and which are chosen purposefully to deal with certain problems in language learning. However, at times they may be used unconsciously on account of mechanical processes that learners perform without noticing, such as creating mental images or relating new information to previous knowledge (Chamot, 2004).

According to the purpose of this study, general learning strategies are used in different educational learning contexts whereas language learning strategies are used when learning English. For general learning, the first-year students in a university context obtain information and knowledge from different subjects, and they have to deal with a variety of tasks relating to each subject which characterises very specific learning settings. For English learning, it represents a more specific learning context which the same group of students have to select particular learning strategies to contend with their English learning tasks. Learning strategies and English learning strategies are problem oriented. Both are conscious and intentional, purposefully chosen to fulfill learning tasks or learning goals. In this way, one strategy generally works along well with the others. They could be practical or unpractical, could be transferred to diverse activities or learning contexts, and could be set up differently according to a variety of factors (Oxford, 2017).

\section{DIFFERENT TYPES OF LEARNING STRATEGIES}

According to Weinstein and Palmer (2002), categorisations of the learning strategies, based on a cognitive approach, mostly include three types of strategies: cognitive, metacognitive, and resource management strategies which are useful for learners' accomplishment. Cognitive strategies help learners to understand and recall information they have learned, and perform complex tasks. Metacognition strategies are useful for learners to plan, control, and monitor, and evaluate their learning processes to achieve learning goals. These strategies have a high degree of transfer and are used as general learning in different learning contexts. 
Resource management strategies are regarded as supports for learners' academic success, such as time management, environment organisation, and effort management.

Oxford (2011) classified language learning strategies into six categories. First, memory strategies are used for storing information. Second, cognitive strategies relate to a mental approach which helps learners to understand the language they are learning. Third, compensation strategies are useful when learners are having problems of using language for communication. Fourth, metacognitive strategies help learners to manage their own learning. Fifth, affective strategies assist learners who are looking for emotional supports such as confidence. The last one, social strategies relate to any activities which encourage learners to use the language to interact with people. These six strategies can be related, taught, and transferred to different tasks and learning contexts. They might be observable or unobservable as well as they support learning directly and indirectly. Memory strategies, cognitive strategies, and compensation strategies can be categorised into direct strategies whereas indirect strategies include metacognitive strategies, affective strategies, and social strategies.

\section{REPERTOIRE AND TRANSFER OF LEARNING STRAEGIES}

According to Ellis (2008), all learners have their own repertoire of learning strategies they have stored and developed through time and experience. Through learning processes, learners learn strategies either directly or indirectly from various sources and learning activities. After monitoring and assessing, learners choose the strategies which they consider efficient for their learning, and store in their sets of repertoires. Through time and practice, the chosen strategies can be changed and developed progressively in different contexts when learners become advanced in learning. However, it is not necessary that all strategies lead to learning success (Oxford et al., 2014).

Learning strategies can be transferrable to new learning contexts and individual learners choose and develop learning strategies from their repertoires that can help support their learning (Oxford, 1996). Nevertheless, research on strategy transfer to language learning and its effect to language attainment is rarely found. Most of the research focuses on writing and reading skill transfer. James (2010), for example, indicates that transferability of skills from L1 to L2 writing skills can be regulated by the L2 onset level, and language knowledge can be a hindrance of the strategy transfer. The study of Magno and Maxilom (2016) on reading strategy transfer from Japanese to English shows that Japanese reading strategies can be transferred as long as learners have some level of language proficiency to overcome the English language problems. Strategy transfer in the first language context is considered difficult and teachers should be in charge of instructing learners to be able to transfer strategies to new learning contexts.

\section{STRATEGY INSTRUCTION}

The main objective of strategy instruction is to provide learners with the correct use of learning strategies, raise awareness of the benefits of learning strategies, provide models of strategic thinking, offer practice with the new strategies, evaluate the use of the strategy, and promote strategy transfer to new learning activities (Griffiths, 2018). Whether or not the instruction can be beneficial for learners depends on the degree to which they are open to new strategies. Guthrie et al. (2000) postulate this in strategy instruction, claiming that learning strategies are purpose-oriented actions which are normally linked to learners' needs, goals, and motivation and based on various types of learning styles.

Even though a number of studies report that successful learners use a broad range of learning strategies to support their learning success (e.g., Griffiths, 2013; Dörnyei \& Ryan, 2015; Ellis, 2008), there is not much resilient evidence proving that those successful learners 
learn strategies from teachers' instruction or other people informing them the importance of strategy use at an early stage of language learning. It is possible that in later stages of learning learners might be able to use effective strategies in new contexts without any direct instruction from teachers. In this regard, Cohen and Macaro (2007) and Tuckman and Kennedy (2011) suggest that teachers should play an important role in strategy instruction, knowing know how strategies work, what benefit the strategies have for learners, and what methodology is practical for teaching strategies. As a result, learners are encouraged to enlarge their strategy repertoires in order to have more frequent use of their own strategies for better chance of learning success.

\section{RESEARCH ON LEARNING STRATEGIES}

Learners' success is formally measured by academic performance. Many research findings underline that the best predictor of academic performance is the use of strategies that is likely to support learning practice and academic success. The study of Lynch (2010) explores the correlation between students' learning strategies and academic success and found that the use of learning strategies helped the students to achieve their academic goals. Nonetheless, the findings do not explain the extent to which learning strategies consistently affect learning and which academic areas or subjects were promoted more.

Research on the use of learning strategies has a strong impact on academic performance and factors such as motivation, anxiety, and learners' perceptions towards the usefulness of the strategies. The emphasis is on different types of learners using various types of language learning strategies at different frequency of use. Griffiths (2013) reveals that there is a significant difference in the frequency of strategy use between more proficient language learners and less proficient ones. Those who are more skillful and make the most learning improvement use a wider repertoire of learning strategies and have higher frequent use of English learning strategies. Likewise, Castillo and Cordora (2014) indicate that high proficient EFL learners have more frequent use of metacognitive and cognitive strategies than less proficient ones.

Much research in the Thai EFL context also focuses on the link of English learning strategy use and learning success (e.g., Intaraprasert, 2002; Jantawong et al., 2018; Kaotsombut, 2003; Pathomchaiwat, 2013; Phonhan, 2016). For example, research of Jantawong et al. (ibid.) on language learning strategies of Thai EFL learners proved that successful language learners had high frequency of use of English learning strategies. Similarly, the study of Pathomchaiwat (ibid.) reported that undergraduate students habitually used affective and compensation strategies which had the most significant effects on English learning achievement. Besides, the students admitted that academic success was not only connected to the strategy use but also other factors such as personal and family complements as well as contributed time and commitment for learning. In recent years, there has been growing interest in the benefit of English strategy instruction on Thai EFL learners. Chumworatayee (2017), for instance, explored possible effects of the implementation of English reading strategy instruction of English reading. After one-semester implementation of the strategy instruction, more students' awareness of the overall reading strategies was marked. Direct explanation of strategies and the strategy instruction were proved as keys for English learning success.

Although there is a lot of literature review and research on learning strategies in various aspects, the ELF context of this study still needs particular research giving an insight into the university students' use of general learning strategies and English learning strategies, importance and benefits of the use of those strategies, sources of the frequency of the strategy use, conscious purposes for using the strategies in the two learning contexts, how and when 
the students use language learning strategies, as well as whether or not the strategy transfer and the strategy instruction will provide predictive and long-lasting effects and help enhance the students' academic performance.

\section{METHODOLOGY}

\section{RESEARCH SAMPLING AND SETTING}

From the total number of all 635 Thai EFL students enrolling the foundation English course (ENG I) as a compulsory subject, 219 students were purposively selected to participate in this study. The participants were first year undergraduate students from different areas of studies at a university in Thailand. The researcher arranged with the course coordinator that only one teacher could teach the four classes in order to have the most unified teaching methodology in both the control and the experimental groups.

\section{RESEARCH METHODS AND RESEARCH INSTRUMENTS}

The study employed a mixed-methods approach which included both quantitative and qualitative data collection methods with the aim to analyze analyse research questions from different angles and to triangulate data gathered from various methods. In accordance with this, Cresswell and Cresswell (2018) explain that research that involve collecting, analysing, and integrating quantitative and qualitative methods provides the greater result of the whole study and a better understanding of the research problem than either of each one alone. A quasi-experimental methodology was conducted throughout the course length (15 weeks) with control and experimental groups. This research design was useful when a researcher had to take existing groups rather than drawing on random samples (Cohen, 2010).

Five research instruments were employed to collect quantitative and qualitative data. First, the questionnaire exploring the students' general learning strategies was modified and adapted from the Learning and Study Strategies Inventory (LASSI) developed by Weinstein and Palmer (2002). It has been largely used to explore general factors that contribute significantly to succeed in academic learning and language learning in higher education; its validity and reliability have been acknowledged worldwide. The questionnaire consists of 45 statement items representing five types of learning strategies: Cognitive Learning (COG), Organisational Learning (ORG), Concentration (CON), Motivation and Goal Orientation (MOG), and Cooperation and Interaction (COI). Frequency of strategy use was measured through 5-point rating scales. Three experts in the field of learning strategies validated the appropriateness of the items and classified them in dimensions by means of the Q-sorting technique (Brown, 2010). Cronbach test for reliability for each of the factors indicates levels from 0.07 to 0.87 and an interval consistency at a global level of 0.91 .

Second, the English learning strategy questionnaire consists of the same strategies used in the language learning strategy questionnaire. However, there are some changes for the specificity of the English learning context. The data of the learning strategy questionnaire and the English learning strategy questionnaire can be linked in order to enable contrasting the strategies the students have in both learning contexts. The dissimilarity helps identify the transfer of learning strategies in general to English language learning. Third, semi-structured interviews add a qualitative dimension to the study, complement the quantitative findings of the questionnaires, probe and expand in detail (Cresswell \& Cresswell, 2018). The interviews were used for exploring more insights into the students' use of learning strategies in general 
and English learning, their perceptions towards difficult areas in English learning and the strategies used for solving such difficulties.

Fourth, the strategy instruction given to the students consists of five stages of the instruction: explanation, model, practice, evaluation, and transfer with the aim to raise the students' awareness of strategy use and instruct them about the benefits of using the strategies. During each of the three instruction sessions, the students were always encouraged to discover new strategies in order to help them achieve their learning goals and to evaluate their learning procedure. Fifth, the English test which was designed based on the course content and its quality standard was officially assessed by the internal and external academic committees of the English department. The same test was applied both at the beginning and the end of the course in order that the results of the pre-test and the post-test could be compared.

\section{DATA COLLECTION}

The study followed a three-phase data collection procedure. In the first phase, in the second week of the course all the learners (109 from the control group and 110 from the experimental groups) were asked to do the English test in order to observe their current knowledge of English in general. They were instructed that the test results would help the teacher to identify the areas which needed to be worked more deeply in order to direct efforts and improve teaching practice as well as the scores would not affect their grades. After that the learning strategy questionnaire were administered and the purpose of the study were informed to assure that their contributions would be taken seriously and act on. The data collected were mainly about the repertoire of strategies they had, strategy types they knew, and frequency of strategies they used before enrolling the ENG I course. The analysis of the questionnaire data was completed before the start of the follow-up interviews.

In the second phase, the students in the experimental group received a treatment by means of three-strategy instruction sessions in the second week after completing the learning strategy questionnaire, in the eighth week, and in the last week (the 15th week). On the third phase, in the last week of the course, 32 students were selected from the control and the experimental groups for individual interviews. After that the English learning strategy questionnaire was applied to the control and the experimental group in order to observe changes in types and frequency of strategy use. Finally, the students in both groups did the final test of learning achievement.

\section{DATA ANALYSES}

The SPSS was used to run specific statistical tests to analyse the data obtained from the learning strategy questionnaire and the English learning strategy questionnaire as well as the pre- and post-achievement tests of the experimental group and the control group. Cronbach's alpha analysis was used to examine reliability of the two questionnaires. Reliability analysis was also applied to strategies computed into eight categories to experimental and control groups in order to observe the reliability of the modified questionnaire and the changes that might occur with strategies as components of the whole questionnaire and strategy types.

Average frequency of the strategy use in general learning computed into categories was compared with English learning strategies and was reported across all the student participants in order to identify the most and the least used strategies in both strategy questionnaire administrations. A Pearson product-moment correlation analysis was carried out to see whether there was the statistically significant correlation between the achievement test scores and the general learning strategies of all groups and in both administrations. 
T-test for two samples was used for identifying significant differences in the frequency of the use of learning strategies and the achievement scores of all groups. Top and bottom quartiles were obtained to determine high and low frequency of use of general learning strategies and English learning strategies. The data were also grouped into categories of high and low achievers as well as high and low strategy users. T-test for paired samples was employed to show the difference between the two groups in the first and the second administration of the achievement test and the two strategy questionnaires.

A regression analysis was used to identify strategies that possibly contribute to achievement or possible predictors for learning achievement of both groups of learners. All interviews were recorded and transcribed verbatim for the data analysis. A content analysis was also used to examine qualitative data. The data were coded and arranged into broader themes and issues concerning the use of learning strategies and English learning strategies.

\section{FINDINGS AND DISCUSSION}

\section{THE STUDENTS' USE OF LEARNING STRATEGIES}

In response to the first research question focusing on the extent to which the students $(\mathrm{N}=$ 219) used general learning strategies, a T-test for independent samples between the control group $(\mathrm{M}=3.25, \mathrm{SD}=.55)$ and the experimental group $(\mathrm{M}=3.44, \mathrm{SD}=.53$ indicated that there was a significant difference between the samples $(\mathrm{t}=2.142, \mathrm{p}>.031)$. The experimental group had a significantly more frequent use of learning strategies. For the learning strategy questionnaire, a mean score above $\mathrm{M}=3.70$ was considered a high strategy use while an average score below $\mathrm{M}=3.14$ was considered a low strategy use. The average across all the student participants $(\mathrm{M}=3.35, \mathrm{SD}=.55)$ suggested a medium strategy use.

With the mean score above 3.70, the ten most frequently used strategies shown in Table 1 represent what strategies the students mostly used as the basis of their learning in general. Noticeably, five out of the ten strategy items were categorised into MOG strategies followed by COG and COI strategies.

TABLE 1. The Most Frequently Used Learning Strategies

\begin{tabular}{|c|c|c|c|c|}
\hline No. & $\begin{array}{l}\text { Strategy } \\
\text { Category }\end{array}$ & & Item & $\begin{array}{c}\text { Mean } \\
(M)\end{array}$ \\
\hline 1 & MGO & 3 & I am concerned about having more learning improvement. & 4.36 \\
\hline 2 & MGO & 38 & $\begin{array}{l}\text { To achieve a learning goal, I try to understand what a lesson is } \\
\text { about. }\end{array}$ & 4.32 \\
\hline 3 & COG & 10 & $\begin{array}{l}\text { Before answering questions, I try to understand them clearly and } \\
\text { obtain accurate information. }\end{array}$ & 4.28 \\
\hline 4 & MGO & 28 & I do my best when doing homework and assignments. & 4.23 \\
\hline 5 & $\mathrm{COI}$ & 13 & I can learn from my classmates' inputs and experiences. & 4.15 \\
\hline 6 & MGO & 11 & $\begin{array}{l}\text { I stay motivated for studies in order that I can get good marks in } \\
\text { exams. }\end{array}$ & 4.09 \\
\hline 7 & MGO & 36 & I keep reviewing a difficult topic until it becomes easier to learn. & 3.94 \\
\hline 8 & $\mathrm{COG}$ & 21 & $\begin{array}{l}\text { I relate what I am learning with my previous knowledge and } \\
\text { experience. }\end{array}$ & 3.85 \\
\hline 9 & COI & 22 & $\begin{array}{l}\text { I participate a group work with classmates and proceed to the } \\
\text { completion of work. }\end{array}$ & 3.78 \\
\hline 10 & $\mathrm{COG}$ & 37 & $\begin{array}{l}\text { I imagine what the text explains and understand it through thoughts } \\
\text { and senses. }\end{array}$ & 3.74 \\
\hline
\end{tabular}

NB: $\mathrm{COG}=$ cognitive learning strategies; $\mathrm{ORG}=$ organisational learning strategies; $\mathrm{CON}=$ concentration strategies; $\mathrm{MGO}=$ motivation \& goal orientation strategies; $\mathrm{COI}=$ cooperation and interaction strategies 
The qualitative findings also supported that the learners used a higher number of ORG strategies which indicated that the learners frequently used strategies that helped them review information learned. Mostly, they used the ORG strategies, for example, when reading and rereading books as a way of reviewing what they had learned in class. They also reported that the strategies allowed them to avoid confusion and solve misunderstanding of the lesson. When feeling uncertain, they would search for ways to clarify a lesson and a teacher's explanation so that the knowledge was organised and stored. As one of them [L4] elaborated, "When I don't understand the lesson in class, I will ask my classmates and if they cannot help me, I will search on either the Internet or textbooks. If I still feel unclear, I will ask a teacher directly." Learners also reported frequent use of COG strategies. Although both high and low strategy users were on opposite sides of the continuum of strategy use, they used the very same strategy but possibly with different results. This finding supported the idea that learning strategies work differently in learners. For example, a high strategy user [L8] and a low strategy user [L20] reported using the COG by relating what they were learning with previous knowledge and experience; as a result, they got new information.

The ten least frequently used strategies with the mean score below 3.13, as shown in Table 2, represented learning strategies at low rate frequency. Among the learning strategies that the learners indicated not using very frequently, ORG strategies apparently had a strong preference, followed by COI and COG strategies. However, it could not be confirmed that those were not advantageous for the students' learning. Possibly, they may use different strategies that were also considered supportive for achieving their learning goals.

TABLE 2. The Least Frequently Used Learning Strategies

\begin{tabular}{|c|c|c|c|c|}
\hline No. & $\begin{array}{l}\text { Strategy } \\
\text { Category }\end{array}$ & & Item & $\begin{array}{c}\text { Mean } \\
(M)\end{array}$ \\
\hline 1 & $\mathrm{COI}$ & 2 & $\begin{array}{l}\text { I have interactions to a teacher and classmates to develop my } \\
\text { learning and social skills. }\end{array}$ & 3.14 \\
\hline 2 & ORG & 32 & $\begin{array}{l}\text { I take notes and do exercises in order to learn in more detail of each } \\
\text { topic. }\end{array}$ & 3.08 \\
\hline 3 & ORG & 9 & I search for books and resources to complement what I have learned. & 3.02 \\
\hline 4 & $\mathrm{COI}$ & 7 & $\begin{array}{l}\text { Before an exam, I study with my classmates for covering all the } \\
\text { topics. }\end{array}$ & 2.88 \\
\hline 5 & ORG & 34 & $\begin{array}{l}\text { I use mind mapping to structure, classify, visualise, and generate } \\
\text { ideas while learning. }\end{array}$ & 2.61 \\
\hline 6 & ORG & 35 & I jot down questions and answer them in second reading. & 2.48 \\
\hline 7 & ORG & 1 & I have an everyday plan for my learning activities. & 2.35 \\
\hline 8 & $\mathrm{COG}$ & 26 & $\begin{array}{l}\text { After each class, I ask myself questions to confirm what I have } \\
\text { learned and what I need to study further. }\end{array}$ & 2.27 \\
\hline 9 & COI & 31 & After reading, I gather with classmates to discuss important points. & 2.01 \\
\hline 10 & COG & 12 & $\begin{array}{l}\text { I develop a new idea and/or a different hypothesis after solving a } \\
\text { problem. }\end{array}$ & 1.96 \\
\hline
\end{tabular}

Nevertheless, the interview data revealed a higher use of ORG strategies for the reason that the learners did not perceive the strategies as learning activities. Many of them admitted that they usually asked teachers and/or other high achieving classmates for clarifying what they did not understand. They not only allotted time for their study, but also looked for further information in books, the Internet, and other available sources of knowledge. As one of them [L29] added, "Certainly we regularly highlight important information when we study and read books. My friends and I always share what we noted or summarised so that we could understand and memorise. This will be useful for the exams and next lessons." 
Besides, the learner interviewees elaborated more on the use of COI strategies. For example, one of the low strategy users [L16] shared some of her experiences. "I like gathering with friends as we can make a brief of what we've learned in class or what we've read from the articles. Also, we share lecture notes and ask questions to what we don't understand." This could be inferred that the students may be unable to specify in the questionnaire what the exact general learning strategies they used, but a number of strategies used could be elaborated in the interview.

The findings in response to the first research question could lead to some interesting points of discussion. The frequency of use in general learning strategies, whether or not it was high or low, did not imply that the students use the learning strategies more or less efficiently. Rather, their use was liable to their personal interest, experience, and motivation. The use of MGO strategies were primarily considered useful for learning in general learning contexts and this was in accordance with the theory of achievement motivation which emphasised that students' experiences and attempts are important for achieving expectable goals (Dörnyei, 2015). Motivation was an unconscious practice which drove students to reach success and move forward to other achievement situations in later stages of learning. In this regard, the students' efforts, needs, and motivation to some extent could had a lot of influence on their learning goals. Accordingly, Cohen and Macaro (2007) raised an interesting issue considering whether the use of learning strategies was conscious or unconscious for the students to consider as strategies. Hadfield and Dörnyei (2013) gave an interesting remark that if the behaviours were conscious, they could be strategies. The current study revealed that most of the strategies were used consciously. ORG and COI strategies were employed purposefully and played an important role in acquiring knowledge. Nevertheless, MGO strategies were considered as unconscious desire and were unconsciously used. They played a vital role in the students' learning determination, encouragement, and effort.

\section{THE TRANSFER OF LEARNING STRATEGIES TO ENGLISH LEARNING STRATEGIES}

In response to the second research question, what general learning strategies were transferred to English learning strategies were examined. A t-test for paired samples between learning strategies in general and English learning strategies employed across all the students did not show a significant difference $(\mathrm{t}=-.621, p>.506)$. The use of strategies was similar in both learning contexts. The students did not either increase or decrease the use of general learning strategies in English learning.

The average frequency of English learning strategy use was calculated across all 219 student participants $(\mathrm{M}=3.39, \mathrm{SD}=.50)$ and they indicated a medium use of the strategies. Mean scores lower than $\mathrm{M}=3.08$ were found on the first quartile which indicated a medium use whereas mean scores of $\mathrm{M}=3.87$ or above were found on the top quartile which indicated a high frequency of strategy use. The ten strategies with the highest mean scores of the English learning strategy questionnaire represented approximately the top quartile and fell into the high frequency category. Table 3 shows the list of ten most frequently used strategies in English learning.

TABLE 3. The Most Frequently Used of English Learning Strategies

\begin{tabular}{ccclc}
\hline No. & $\begin{array}{c}\text { Strategy } \\
\text { Category }\end{array}$ & & Item & $\begin{array}{c}\text { Mean } \\
(M)\end{array}$ \\
\hline 1 & MGO & 3 & I am concerned about having more learning improvement. & 4.29 \\
2 & COI & 13 & $\begin{array}{l}\text { I can learn from my classmates' inputs and experiences. } \\
\text { When a teacher mentions a particular topic in class, I try to }\end{array}$ & 4.28 \\
3 & COG & 17 & 4.15 \\
4 & ORG & 39 & $\begin{array}{l}\text { understand by thinking of what I know about it. } \\
\text { To remind what I have learned, I jot down important keywords after }\end{array}$ & 4.10
\end{tabular}




\begin{tabular}{ccccc}
5 & COG & 21 & $\begin{array}{l}\text { learning a particular topic. } \\
\text { I relate what I am studying with my previous knowledge and } \\
\text { experience. }\end{array}$ & 4.06 \\
6 & COG & 37 & $\begin{array}{l}\text { I imagine what the text explains and understand it through thoughts } \\
\text { and senses. }\end{array}$ & 4.02 \\
7 & MGO & 28 & $\begin{array}{l}\text { I do my best when doing homework and assignments. } \\
\text { When reading, I highlight the most important concepts and ideas to } \\
\text { help me remind them later. }\end{array}$ & 3.01 \\
9 & COG & 19 & $\begin{array}{l}\text { When starting studying, I try to continue or maintain the proper } \\
\text { focus. } \\
\text { Iparticipate a group work with classmates and proceed to the } \\
\text { completion of work. }\end{array}$ & 3.98 \\
10 & COI & 22 & 3.84 \\
\hline
\end{tabular}

NB: COG = cognitive learning strategies; ORG = organisational learning strategies; $\mathrm{CON}=$ concentration strategies; $\mathrm{MGO}=$ motivation $\&$ goal orientation strategies; $\mathrm{COI}=$ cooperation and interaction strategies

COG strategies were found more often on the list of the most used English learning strategies. This could be implied that the students used the strategies to help facilitate their English learning, particularly when dealing with new information and learning activities. MGO and COI strategies were also popular for the English learning. CON and ORG strategies were also mostly used respectively.

From the interview, more strategies for English learning with greater detail were reported. ORG strategies were used the most frequently and many strategies under this strategy category were mentioned. For example, the students regularly took notes, reviewed what they had learned, did English exercises and practices as part of their language learning. COG strategies, relating new information to known information, were highlighted by both high and low strategy users. Students shared similar experience of creating their own examples to understand meanings and to learn grammatical structures. As one [L26] said, "When encountering a difficulty applying grammatical knowledge into practice, I create my own examples of the structures which is easier to understand and remember." This could be implied that COG strategies could be part of the students' repertoires that they used to comprehend new information of a new language.

CON strategies were also mentioned largely. Many learners referred to the way in which they paid attention to English pronunciation, listening, and reading practices. One of them [L12], for example, remarked that she always paid attention to how a speaker pronounced a word and tried to imitate. Paying attention and concentrating in class, or on what they listen to or read, were strategies that the students reported as characteristics of good language learners. A low strategy user [L25] said, "A good learner is a person who pays good attention to the study, asks questions, and participate well in class. As a result, I believe that good test scores and learning achievement will pay off the learner's effort."

Table 4 below shows the least frequently used of English learning strategies with the lowest mean scores lower than $\mathrm{M}=3.07$. Noticeably, among the ten strategies, the students did not use ORG and COI strategies very frequently. This could be implied that they may prefer using different types of strategies when learning English.

TABLE 4. The Least Frequently Used of English Learning Strategies

\begin{tabular}{ccclc}
\hline No. & $\begin{array}{c}\text { Strategy } \\
\text { Category }\end{array}$ & & Item & $\begin{array}{c}\text { Mean } \\
(M)\end{array}$ \\
\hline 1 & COI & 7 & $\begin{array}{l}\text { Before an English exam, I study with my classmates for covering all } \\
\text { the topics. }\end{array}$ & 2.55 \\
2 & ORG & 35 & $\begin{array}{l}\text { Ijot down questions and answer them in second English reading. } \\
\text { After reading in English, I gather with classmates to discuss } \\
\text { important points. }\end{array}$ & 2.56 \\
3 & COI & 31 & $\begin{array}{l}\text { I choose to sit in the front seat to keep myself motivated and for the } \\
\text { best attention in an English class. }\end{array}$ & 2.50 \\
4 & MGO & 5 & After each English class, I ask myself questions to confirm what I & 2.39 \\
5 & COG & 26 &
\end{tabular}




\begin{tabular}{|c|c|c|c|c|}
\hline & & & have learned and what I need to study further. & \\
\hline 6 & ORG & 1 & I have an everyday plan for my English learning activities. & 2.26 \\
\hline 7 & ORG & 34 & $\begin{array}{l}\text { I use mind mapping to structure, classify, visualise, and generate } \\
\text { ideas while learning English. }\end{array}$ & 2.05 \\
\hline 8 & ORG & 15 & I read beforehand what I have to study in an English class. & 1.95 \\
\hline 9 & $\mathrm{COG}$ & 12 & $\begin{array}{l}\text { I develop a new idea and/or a different hypothesis after solving a } \\
\text { problem concerning English language learning. }\end{array}$ & 1.93 \\
\hline 10 & $\mathrm{COI}$ & 29 & $\begin{array}{l}\text { When carrying out a group activity in an English class, I make sure } \\
\text { what a topic is about so that the learning activity proceeds smoothly. }\end{array}$ & 1.84 \\
\hline
\end{tabular}

As shown in Tables 1, 2, 3, and 4, MGO, COG, COI, and ORG strategies were transferred from general learning contexts to English learning contexts. A pair sample t-test generally indicated that types of strategies used in both contexts were not much different and show insignificant changes in recurrent use. The learners increased the use of some strategies whereas they decreased in the use of others. Noticeably, the frequency of use of COG strategies (from $\mathrm{M}=3.60$ to 3.75) and COI strategies (from $\mathrm{M}=2.99$ to 3.29) showed an increase in average from general learning to English learning. On a contrary, MGO and ORG strategies indicate a decrease in average scores (from $\mathrm{M}=3.67$ to 3.49; and from $\mathrm{M}=2.98$ to 2.78 respectively). To some extent, the learning strategies used in English learning seemed to be influenced by the strategies the students had in their strategy repertoires. They either adapted their strategies to new learning activities or adopted the new ones.

In the interview, the students complemented the data from the questionnaire survey. For example, they used a great extent of ORG strategies such as taking notes, making summaries, and doing homework in both general learning and English learning contexts. Many of them admitted that ORG strategies were useful for managing their study practices such as requesting for clarification, allocating time for studying, and practicing English. From the data obtained, the students had strategy repertoires that they had developed through years and experience. The interview allowed the students to explain more on the use of strategies for English learning; however, any uses of MGO and COI strategies in particular were not mentioned. This could be perceived that the students only reported what the strategies they recalled using, and they were unlikely to identify strategies they instinctively employed.

The discussion in response to the findings of the second research question concerned the strategy transfer from general learning to English learning. According to Ellis (2008), learning strategies could be adopted and changed through time and experience. The data obtained from the questionnaire survey and the interview indicated that individual students kept strategies they considered useful in their repertoire for later applications in other learning contexts. When starting new learning, the students chose strategies they consider useful for particular learning tasks. Various strategies such as taking notes, memorising information through imagery, repeating information for later retrieval, and asking for clarification were common strategies that the students usually used when learning in general contexts. To facilitate their English learning, some of the strategies were developed or changed appropriately according to particular learning situations.

At an early stage of English learning at university level, the students may be unable to completely transfer or develop learning strategies from their repertoires. In addition, the learning activities may not need an application of different or more advanced learning strategies, or they may be unaware of new methods for learning the language. Thus, the strategies used in English learning were similar to the strategies used in general learning. As stated by Davidson and Stenberg (2003), learners did not habitually transfer strategies used in one learning context to another and are unlikely to develop new strategies whenever they 
were in a new learning context. They usually limited a strategy to the learning context where they learned to use the strategy.

As being adult learners at university level, the students were not likely to see English learning as a new experience. Many strategies had been collected and kept in individual students' repertoires through various English learning contexts. The use of various strategies inferred a particular learning experience and a different perspective of what the students' current language learning was for. Dörnyei (2005), therefore, postulated that language learning experiences to some extent influenced individual learners' effort to learn the language.

In this regard, as can be seen from the findings, the way in which the students made use of strategies was in relation to metacognitive knowledge retrieved from their learning experience. Castillo and Cordora (2014) pointed out that learning strategies were correlated to metacognitive and self-regulated learning activities which included abilities to guess, plan, evaluate, and monitor knowledge competently. This was also corresponding to the study of James (2010) emphasising that strategies concerning metacognition were interrelated to learners' English proficiency and frequent use of learning strategies.

\section{THE PREDICTION OF THE STUDENTS’ ENGLISH LEARNING ACHIEVEMENT}

In response to the third research question, the students' achievement test scores were compared with their strategy use in order to predict the English learning achievement. The average score of the test was $\mathrm{M}=34$ which indicated that the students were medium-high achievers. A t-test for independent variables indicated equal variance $(p=.178)$ and the significance $(\mathrm{t}=1.645, \mathrm{p}<.910)$ specified that the pre-achievement test scores of the two groups were similar and consistent. The post-test scores also showed equal variance and indicated no significant difference in the test scores $(p<.832)$ between the two groups. This showed that the students in both groups had similar English language knowledge.

A Pearson correlation test showed a significant relationship $\mathrm{P}$ value $(\mathrm{p}>.001, \mathrm{r}=$ .311) which indicated that the use of learning strategies affected the students' English learning achievement. The correlation analysis revealed that MGO strategies were found as frequently used strategies both in overall analysis and as strategies computed into categories. ORG strategies identified as not frequently used at a strategy level and in categories of strategies indicated no correlation with the achievement test scores.

The correlation analysis corresponded to the predictive values of the beta coefficients in the regression model. Regression analysis was also carried out to predict the value of the test scores based upon the use of learning strategies classified into five learning strategy types. It was found that the achievement test scores were primarily predicted by the use of MGO and COI strategies which had significant positive regression weights. Students with higher scores on these scales were expected to have higher test scores after controlling for the other variables in the model. ORG strategies showed a significant negative weight; thus, students with higher use of these strategies were expected to have lower test scores. COG and CON strategies indicated a negative weight to a less significant extent; in this regard, higher achieving students would make use of different strategies to achieve higher test scores.

Accordingly, qualitative data from the interview revealed that there was a correlation between high strategy use in general learning and high achievement in English learning. This was illustrated by many students having a high use of both general learning strategies and English learning strategies. Nonetheless, their achievement test scores were not found in either high or low achievement category. The strategies used did not boost them to reach higher levels of English learning achievement. In contrast, some other students showed a high 
strategy use in general learning although their achievement test scores fell into the category of low English learning achievers.

Interestingly, there was a case of a low achieving learner with a lot of English learning experience [L14]. He was categorised into the group of low strategy users in general learning but a high strategy user in English learning. Interestingly, he attained the test scores on both pre- and post-achievement tests (36 and 38 respectively) higher than the mean scores $(\mathrm{M}=34)$. Another one [L32] could be considered as a high achieving learner in both pre- and post-achievement tests (42 and 45 respectively); however, she was a low strategy user in both general learning and English learning. The high scores might be attributed to either their previous English learning knowledge or their best luck of choosing most of the right answer on the test.

The findings in response to the third research question regarding the strategy use and learning achievement can lead to some interesting points of discussion. Strategy use becomes increasingly focused when the students switched learning activities from general to specific goals. An increase of strategy use shown in the qualitative data can be explained that there were continuous and relative changes in the students' learning practices. Accordingly, Oxford (2011) indicated that language learning strategies were deliberate actions chosen for goal achievement and goals could be changed during the learning process. Thus, it was comprehensible that the strategy use could be changed; the students may find other strategies to deal with language learning. Once learning became more specific and the goals were more focused, the students inevitably needed specific strategies to be implemented. This coincided with Griffiths' (2013) supposition that learners of different levels used various types of strategies and at different rate of recurrence.

Considering the extent to which learning strategies predicted English learning achievement, the findings of this study revealed that to some degree general learning strategies transferred to English learning could predict language learning achievement. Research on English learning strategies (e.g., Anugkakul, 2011; Castillo \& Cordora, 2014; Domakani et al., 2012. Jantawong et al., 2018; Lynch, 2010; Mochizuki, 2016; Tuckman \& Kennedy, 2011) revealed that a high frequent use of strategies had an impact on English learning. In this study, MGO strategies indicated highest correlation with the achievement test scores, and the strategies were enlisted in the ten most frequently used strategies for general and English learning. Accordingly, motivation and goal orientation were mechanism which the students had acquired and developed through their learning experience and helped them accomplish new learning situations.

Looking into the reasons why in this study the strategies concerning achievement motivation played an important role in English learning, much research on learning motivation focused on internal and external factors which to some degree had a lot of influence on learners' interest in their learning and learning achievement (e.g., Bernaus et al., 2009; Guthrie et al., 2000; Kitjaroonchai \& Kitjaroonchai, 2012; Lynch, 2010; Suliman, Yunus \& Nor, 2019). Dörnyei (2005) explicated that motivation for learning achievement consisted of two variables concerning the tendency to approach success and to avoid failure. It was possible that the higher use of motivation strategies was attributable to the drive to pass the course rather than to achieve learning goals. Thus, a large number of the students were motivated to learn English by means of a greater desire to pass the courses taken. Singh (2011) also emphasised that learners with high frequency of use of MGO strategies were liable to having better attitudes to difficult learning activities.

Besides, to a lesser extent, COI strategies apparently related to a prediction of English learning achievement. Harrish (2014) asserted that powerful relationship among social interaction of students and a teacher, the learning context, and the language was crucial for successful English learning. Interaction was entirely related to variation of learning activities 
which required interaction with a teacher and classmates. Once the language was put into practice, the students' communicative competence and English proficiency could be developed.

Although the quantitative data explicitly indicated that general learning strategies had a positive effect on English learning achievement, the qualitative data approved that the finding could not be generalised. High strategy use in general learning declined in English learning and the high strategy users could not make good progress in English learning as shown in the achievement test scores and the information given in the interview. Likewise, it was apparent that some other high strategy users in English learning were not considered as high achieving students. Thus, the high degree of strategy use was unlikely to positively affect the English learning achievement. This could be speculated that the students may use the strategies which did not largely facilitate their learning. Strategy instruction, therefore, would be a guidance for the students how to make use of strategies when learning English.

\section{THE ROLE OF STRATEGY INSTRUCTION IN THE USE OF ENGLISH LEARNING STRATEGIES}

In response to the fourth research question, how the strategy instruction played a role in the students' use of English was explored. Eight strategies which were not frequently used were chosen for the strategy instruction session with an expectation that they would have an increase in the frequency of use after the instruction. A statement of each strategy was restated and revised for the most effective strategy instruction sessions. To determine the effectiveness of the strategy instruction, mean scores of the learning strategy questionnaire and English learning strategy questionnaire were collected in order to observe the average frequency of use. A t-test for paired samples was carried out to the chosen strategies in order to analyse the effect of the strategy instruction.

To determine the effectiveness of strategy instruction, a lesson plan was developed in accordance with the selected strategies and the statement of each strategy was paraphrased and rearranged. The mean scores of the learning strategy and the English learning strategies were obtained in order to observe the average frequency of use. A t-test for paired samples was carried out to the chosen strategies in order to analyse the effect of strategy instruction. Table 5 below presents averages of general learning strategies and English learning strategies as well as $p$ values of the t-test for paired samples.

TABLE 5. Paired Sample t-test of the Strategies Used in Strategy Instruction

\begin{tabular}{|c|c|c|c|c|c|c|}
\hline No. & $\begin{array}{l}\text { Strategy } \\
\text { Category }\end{array}$ & & Item & $\begin{array}{c}\text { General } \\
\text { Learning } \\
\text { (M) }\end{array}$ & $\begin{array}{c}\text { Language } \\
\text { Learning } \\
\text { (M) }\end{array}$ & $\begin{array}{l}\text { t-test } \\
\text { (Sig.) }\end{array}$ \\
\hline 1 & COG & 19 & $\begin{array}{l}\text { Highlighting the most important concepts } \\
\text { and ideas }\end{array}$ & 3.40 & 3.94 & .012 \\
\hline 2 & $\mathrm{COG}$ & 20 & Putting knowledge into different practices & 3.55 & 3.57 & 1.125 \\
\hline 3 & COG & 23 & $\begin{array}{l}\text { Restate the important point that still } \\
\text { express the original idea and understanding }\end{array}$ & 3.56 & 3.66 & .635 \\
\hline 4 & COG & 26 & $\begin{array}{l}\text { Reflecting on learning experiences and } \\
\text { activities }\end{array}$ & 2.60 & 2.77 & .354 \\
\hline 5 & ORG & 27 & $\begin{array}{l}\text { Discerning and summarising the most } \\
\text { important points and ideas }\end{array}$ & 3.53 & 3.56 & .839 \\
\hline 6 & ORG & 34 & $\begin{array}{l}\text { Visually mapping out thoughts and ideas } \\
\text { around the topic }\end{array}$ & 2.17 & 2.97 & .008 \\
\hline 7 & ORG & 35 & $\begin{array}{l}\text { Asking questions and getting answers for } \\
\text { the best evidence of understanding }\end{array}$ & 2.88 & 2.75 & .521 \\
\hline 8 & $\mathrm{COI}$ & 31 & $\begin{array}{l}\text { Having peer interactions to enhance } \\
\text { learning capacity }\end{array}$ & 2.35 & 2.42 & 698 \\
\hline
\end{tabular}

NB: $\mathrm{COG}=$ cognitive learning strategies; $\mathrm{ORG}=$ organisational learning strategies; $\mathrm{CON}=$ concentration strategies; $\mathrm{MGO}=$ motivation $\&$ goal orientation strategies; $\mathrm{COI}=$ cooperation and interaction strategies 
The use of these strategies increased in average from the first to the second questionnaire administration. There was a significant increase in average scores on the strategy item 34 (ORG) "Visually mapping out thoughts and ideas around the topic" and 19 (COG) "Highlighting the most important concepts and ideas". These strategies represented learning strategies in general that the students used across learning contexts. The increase of these two as well as another on the strategy item 26 (COG) "Reflecting on learning experiences and activities" also remained in the list of the ten least frequently used strategies in the English learning questionnaire. This could be assumed that the learners used other strategies that would help them in English language learning. Remarkably, item 35 showed a decrease which inferred that the students used this strategy in general learning more frequently than in the English learning. In this regard, the students may need more English proficiency when using this strategy in the language learning activities.

Interestingly, the students reported in the interview that they practiced as a common strategy in different ways, such as pronouncing words along with listening drills, speaking with foreign teachers and friends, watching international movies, and listening to songs and reading through their lyrics in English. As one [L19] explained, "I like learning through practices. It's such an enjoyment when watching English cartoons, movies, and TV series with subtitles. In doing so, I can comprehend the language subconsciously which is my best way of learning English through practices." From both quantitative and qualitative data, various ways of practices could be part of essential characteristics of English language learning; however, they could not be entirely attributed to the language instruction to help improve English language learning.

The findings in response to the fourth research question concerning the influence of strategy instruction on the use of English learning strategies could contribute to several issues. Students in the experimental group receiving strategy instruction did not show any significant higher scores in the achievement test or the increase of the frequency of strategy use. The qualitative data elaborated that the students used various types of strategies and deal with learning tasks with available mechanisms in their repertoire. Besides, the strategies transferred from strategy repertoire may not be ascribed to the specificity of the English learning. The finding concurred with Chamot's study (2005); there was no significant effect of strategy instruction on language learning for both high and low achievers. The main reason was that the students did not find the strategies useful.

Despite the fact that the main objective of strategy instruction was to raise learners' awareness of the benefits of strategies (Haskell, 2001), the findings of this current study revealed that the strategy instruction was unlikely to have any effects on the increment of the frequency of strategy use. The instruction had a positive effect on raising the students' awareness of the benefits of using the strategies, but the awareness triggered the students' desire to look for their strategies to deal with English learning other than the strategies instructed. Even so, the students may not find any strategies taught useful for their English learning. This was corresponding to the study of Liu (2010) explicating that there were many conditions restricting the usefulness of strategy instruction. The instruction could not ascertain that learners were likely to use more strategies. In this study, the strategy instruction, to some degree, helped inform the students how the learning strategies could be useful, but it did not prove whether the strategies instructed were effective for their learning.

Although the teaching of the eight strategies in an explicit way was intended to represent a new way of solving problems concerning tasks in English language learning, the strategies used were taken and adapted from their general learning strategy repertoire. The students may not find the strategies new or appealing to a certain stage of English learning. Additionally, Krashen (2011) commented that at an early stage of learning practice, it may be suitable if the learners were instructed how to make use of some advanced strategies 
concerning prediction and reflection. Other strategies such as summarising and creating mind maps were usually useful for learners in an early stage of learning.

\section{THE RELATIONSHIP OF USE OF STRATEGIES AND LEARNING ACHIEVEMENT}

According to the last research question, it was found that the high achieving students $(\mathrm{N}=$ 50) was associated with a more frequent use of strategies in English learning $(\mathrm{M}=3.60 ; \mathrm{SD}=$ $.43)$ whereas the low achievers $(\mathrm{N}=56)$ was related to a less frequent use of strategies $(\mathrm{M}=$ 3.21 ; $\mathrm{SD}=.57$ ). Considering the mean scores of general learning strategies and English learning strategies as shown in Table 6, high and low achieving students used MGO, COG, and CON strategies at higher rate in both general learning and English learning contexts as they would consider these strategies useful enough to help them to contend with learning.

TABLE 6. Strategy Use of High and Low Achieving Students

\begin{tabular}{|c|c|c|c|c|c|c|c|c|c|}
\hline \multicolumn{5}{|c|}{ High Achieving Students } & \multicolumn{5}{|c|}{ Low Achieving Students } \\
\hline $\begin{array}{c}\text { Strategy } \\
\text { Types }\end{array}$ & $\begin{array}{c}\text { General } \\
\text { Learning } \\
\text { Strategies }\end{array}$ & $\begin{array}{c}\text { English } \\
\text { Learning } \\
\text { Strategies }\end{array}$ & $t$ & Sig. & $\begin{array}{c}\text { Strategy } \\
\text { Types }\end{array}$ & $\begin{array}{c}\text { General } \\
\text { Learning } \\
\text { Strategies }\end{array}$ & $\begin{array}{c}\text { English } \\
\text { Learning } \\
\text { Strategies }\end{array}$ & $t$ & Sig. \\
\hline COG & 3.77 & 3.96 & -1.27 & .201 & COG & 3.64 & 3.54 & .585 & .556 \\
\hline ORG & 2.94 & 2.89 & .215 & .824 & ORG & 3.07 & 2.97 & 1.03 & 290 \\
\hline $\mathrm{CON}$ & 3.57 & 3.90 & -2.39 & .018 & $\mathrm{CON}$ & 3.54 & 3.46 & .965 & .335 \\
\hline MGO & 3.77 & 3.75 & .163 & .863 & MGO & 3.68 & 3.32 & 2.30 & .022 \\
\hline COI & 3.02 & 3.41 & -1.42 & .012 & COI & 3.06 & 3.08 & .233 & .810 \\
\hline Total & 3.41 & 3.60 & 1.09 & .265 & Total & 3.37 & 3.21 & 1.09 & .262 \\
\hline
\end{tabular}

NB: $\mathrm{COG}=$ cognitive learning strategies; $\mathrm{ORG}=$ organizational learning strategies; $\mathrm{CON}=$ concentration strategies; $\mathrm{MGO}=$ motivation $\&$ goal orientation strategies; $\mathrm{COI}=$ cooperation and interaction strategies

Noticeably, the both groups of students had less use of ORG strategies when learning English. Nevertheless, it was found that half of the interviewees categorised as high achievers in English learning reported using a large number of ORG strategies transferred from general learning. The data from the interview could lead to an interesting point that the students used learning strategies which did not provide much beneficial effects on their English learning achievement. The high strategy users tended to increase more use of strategies when learning English. For the low achieving students, the mean scores showed a decrease in more strategy categories from general learning to English learning. Only MGO strategies had a statistically significant decrease in the use from $\mathrm{M}=3.68$ to $\mathrm{M}=3.32$ which indicated that the low achievers became less interested and motivated when learning English. More than half of the interviewees categorised as low achievers of English learning largely admitted that the English learning tasks were difficult and they did not know which strategies could lead them to easier ways for learning achievement.

The relationship between learning strategies and learning achievement was intricate. Learning strategies which were beneficial for some students might not be advantageous for others. High strategy use supported high learning success; however, there might not be an explicit pattern of use due to various factors that could affect their choices. Table 6 shows the average use of general learning strategies and English learning strategies of the high and low strategy users. 
TABLE 7. Strategy Use of High and Low Strategy Users

\begin{tabular}{cccccccccc}
\hline $\begin{array}{c}\text { Strategy } \\
\text { Types }\end{array}$ & $\begin{array}{c}\text { General } \\
\text { Learning } \\
\text { Strategies }\end{array}$ & $\begin{array}{c}\text { English } \\
\text { Learning } \\
\text { Strategies }\end{array}$ & & & Sig. & Strategy & \multicolumn{2}{c}{ Low Strategy Users } \\
Types & $\begin{array}{c}\text { General } \\
\text { Learning } \\
\text { Strategies }\end{array}$ & $\begin{array}{c}\text { English } \\
\text { Learning } \\
\text { Strategies }\end{array}$ & $t$ & Sig. \\
\hline COG & 3.62 & 3.46 & -5.95 & .001 & COG & 3.54 & 3.19 & 2.98 & .003 \\
ORG & 3.16 & 3.50 & -2.25 & 0.30 & ORG & 2.88 & 2.25 & 4.01 & .001 \\
CON & 3.55 & 4.18 & -3.18 & .004 & CON & 3.25 & 3.06 & 1.13 & .258 \\
MGO & 3.74 & 3.94 & -1.81 & .072 & MGO & 3.60 & 2.94 & 5.65 & .001 \\
COI & 3.05 & 3.43 & -3.04 & .028 & COI & 2.95 & 2.82 & -1.30 & .634 \\
Total & 3.41 & 3.93 & -4.94 & .001 & Total & 3.25 & 2.85 & 4.24 & .001 \\
\hline
\end{tabular}

NB: $\mathrm{COG}=$ cognitive learning strategies; $\mathrm{ORG}=$ organisational learning strategies; $\mathrm{CON}=$ concentration strategies; $\mathrm{MGO}=$ motivation \& goal orientation strategies; $\mathrm{COI}=$ cooperation and interaction strategies

Remarkably, low strategy users had less frequent use of all English learning strategies than the use of general learning strategies. They had similar patterns of using the learning strategies in both contexts where MGO, COG, and CON strategies were more frequently used than COI and ORG strategies. When learning English, the low strategy users had less use of ORG and MGO strategies which were used in general learning. Most of the student interviewees admitted that they studied English in order to primarily fulfil the degree requirement rather than intrinsic passion for the language. This may be a reason why they did not put much effort in looking for strategies to improve their English. Despite the decreasing number of ORG strategies, some of the low strategy users made use of the strategies through practices which they found useful in general learning and also transferred them into other learning contexts including English learning. For example, the students reported using rereading and reviewing lessons in both general learning and English learning. One with low strategy use [L13] explained, "It's always been the way I learn and this is a proven strategy that help me. I use this strategy in any learning contexts including the English learning."

Referring to the quantitative data shown in Table 6 and Table 7, it could be observed that the low achieving students and low strategy users decreased in the frequency of strategy use from general learning strategy to English learning strategy. Besides, the low strategy users $(M=2.85)$ reported lower strategy use than the low achieving students $(M=3.21)$. This indicated that the low strategy users had less strategy use from general learning to English learning. Interestingly, the low achievers emphasised a lot more on strategy use; the highest increase was on organisational learning strategies which suggested that low achievement did not certainly signify low strategy use. This might be attributed to different factors such as learning experience, goals for learning, and students' beliefs.

The qualitative data suggested that the high achieving students and the high strategy users showed an increase in the strategy use from general learning to English learning. Both groups explained that they found other ways to deal with English learning tasks. It was interesting that the high achievers and the high strategy users were more proactive learners and that they allotted more time to learning due to higher enthusiasm. For example, one student [L31] who was studying English because she needed it for her future career; however, she felt that she was falling behind the others classmates and colleagues who seemed to be more achieved. The quantitative data also showed that the high achieving students and the high strategy users used similar types of strategies. They more often used COG, CON, and MGO strategies, but not frequently used ORG and COI strategies. This could contribute to the understanding that a higher level of strategy use, to some extent, related to learning achievement.

Nevertheless, there were some exceptions. Some students reporting using less general learning and English learning strategies, but their achievement test scores indicated that they were high achievers. During the interview, some students who obtained high achievement test 
scores revealed that they did not use a lot of strategies and were not aware of what strategies they were using. As one [L34] said, "I just do homework and attend class regularly. I pay attention to class only when it is interesting. I never do any other activities to help learn English. Anyway, I like watching movies and listening to songs in English." There were students who certainly employed a large number of strategies they may not consider as useful for their learning. Mostly, the strategies mentioned in the interview were not included in the questionnaire and they were regarded as COG strategies and relevant to mental process.

Another student [L20] could be an interesting exception. His achievement test scores indicated that he was a low achiever even though he used various general learning strategies and transferred to English learning. However, they did not concretely support his English learning achievement and this case did not indicate the relationship between high strategy use and high achievement. This student revealed that he had difficulty in English grammar. His strategy repertoire might not be adequate as it was found that only jotting down everything the teacher instructed might not give him a necessary tool to comprehend what he was learning.

The discussion in response to the last research question focused on the students' learning achievement and its relationship to their use of learning strategies. Previous language learning experience provided the learners with a certain degree of language knowledge causing them to be more or less advanced. Although the students' knowledge of English was at fundamental level, there are both high and low achieving students in the same class and their strategy use was at a different frequency rate. It was evident that groups of the students used similar strategies but at a different frequency rate. This was in accordance with Lynch (2010)'s study reporting that learners at different levels used different types of strategies, even so the frequency of use was a factor distinguishes them.

The goal in using strategies may be a differentiating factor between the effective or ineffective use of strategies. If watching movies to improve listening comprehension was the case for the low strategy users, the subtitles may be of much help in understanding. However, much of the information understood through movie watching could come from reading subtitles and not from listening. Thus, if students assessed the strategy use based on the results obtained, they might misdirect effort in a reading skill with the intention of improving listening. If students consciously assessed their comprehension after watching movies, they would probably acknowledge the effectiveness of the strategy. Thus, according to Griffiths (2018), it depended on whether or not strategy users purposefully used strategies to pursue a goal in mind. The high strategy users tended to have more metacognitive knowledge which allowed them to identify, monitor, and assess the learning outcomes of the learning process they used.

\section{IMPLICATIONS AND CONCLUSION}

This research attempted to contribute to the current body of research and places its contribution in the transfer and the practical use of the students' general strategy repertoire for particular purposes when they involved in English learning activities. The study provided useful information regarding the learning strategies which the students used to facilitate their English learning and to identify their repertoire of learning strategies used in a new learning context where English learning represented. The findings shed a new light on five categories of strategies which related to learning activities and behaviours that the students used for achieving their learning goals. All the strategies were used consciously and unconsciously not only in general learning but also in English learning contexts. Achieving goals also had a strong impact on learning motivation and persistent behaviours for continuing the lengthy 
process of English learning. Therefore, the strategies could be recognised as a primary technique to be used consciously and unconsciously in both general learning and English learning.

The study also offered some valuable insights into the perspective that the strategy transfer as a result of explicit strategy instruction were needed to consider different variables to have a positive and a greater impact on English learners. Apparently, the students adopted and used the strategies based on their goals, needs, and lacks. To some degree, they may not be well aware of what the appropriate use of the strategies was. Accordingly, such factors were carefully considered as the choice of strategies to be instructed. In doing so, the strategy instruction had more substantial effects on the students' implementation of strategies for their English learning.

Considering the pedagogical implications, the notion that the beginning learners at the university level had an already developed set of strategies that they used across different learning contexts may provide a potential framework to help teachers and other relevant people to identify the need for teaching new and specific teaching strategies. In this regard, it is recommended that strategy instruction be provided more accurately to fill the gap that the English language learners at the beginning level have for English learning strategies.

Besides, the use of new strategies in English learning did not imply that the strategies were advantageous for the beginning learners of the fundamental course. It is, therefore, worth focusing more on the approach to strategy use according to the students' learning goals. For example, listening to video clips on the Internet for improving pronunciation, speaking with English teachers and/or native speakers of English to improve fluency and communication skills, as well as reading authentic materials for gaining more and new vocabulary and evaluating comprehension skills could be useful for identifying and redirecting efforts to more beneficial objectives for English learning and ideally proposing learning strategies for individual learners according to their learning goals. Moreover, strategy instruction should take into account teaching the resolution for using the learning strategies so that the learners can be better equipped with a more accurate set of strategies.

Since the use of strategies was different for English language learners at various levels, the instruction of learning strategies should be matched with the learners' goals, needs, lacks and purposes. Importantly, it is suggested that the learners know what the reasons of using those strategies are, and what the purposes in doing the learning activities are; as a result, the advantages will be given to their learning. Further, teachers should be well aware of the strategies the students use to learn the language. They should be able to be in assistance of their students in choosing learning strategies that are suitable for their lacks and needs. As the study revealed that the students frequently use MGO and COI strategies which were more likely to help the students to gain positive effects on their English learning achievement, teachers should encourage them to more frequently use the strategies.

\section{REFERENCES}

Anugkakul, G. (2011). A comparative study in language learning strategies of Chinese and Thai students: A case study of Suan Sunandha Rajabhat university. European Journal of Social Sciences, 19(2), 163174.

Bernaus, M., Wilson, A. \& Gardner, R. (2009). Teachers' motivation, classroom strategy use, students' motivation and second language achievement. Porta Linguarum. 12, 25-36.

Blasiman, R. N., Dunlosky, J. \& Rawson K. A. (2017). The what, how much, and when of study strategies: Comparing intended versus actual study behaviour. Memory. 25, 784-792.

Brown, S. R. (2010). Q Methodology. In N. J. Salkind (Ed.), Encyclopedia of Research Design (pp. 1149-1155). CA: Sage.

Castillo, M. \& Cordora, K. (2014). Language learning strategies and academic success: A Mexican perspective. Universities Psychological. 13(2), 706-713. 
Chamot, A. U. (2004). Issues in language learning strategy research and teaching. Electronic Journal of Foreign Language Teaching. 1(1), 14-26.

Chamot, A. (2005). Language learning strategy instruction: Current issues and research. Annual Review of Applied Linguistics. 25, 112-130.

Chumworatayee, T. (2017). The effect of reading strategy instruction on Thai EFT adult learners' reading strategy awareness. LEARN Journal. 10(1), 135-148.

Cohen, A. D. (2011). Strategies in Learning and Using a Second Language. London: Longman.

Cohen, A. \& Macaro, E. (Eds). (2007). Language Learner Strategies: Thirty years of research and practice. Oxford: Oxford University Press.

Creswell J. W. and Cresswell, J. D. (2018). Research Design: Qualitative, quantitative, and mixed methods approaches. (5th Edition). London: Sage Publications.

Hadfield, J. \& Dörnyei, Z. (2013). Motivating Learning. London: Pearson Education Limited.

Davidson, J. \& Sternberg, R. (2003). The Psychology of Problem Solving. Cambridge: Cambridge University Press.

Domakani, M. R., Roohani, A. \& Akbari, R. (2012). On the relationship between language learning strategy use and motivation. 3L: Language, Linguistics, Literature. 18(4), 131-144.

Dörnyei, Z. (2005). The Psychology of the Language Learner. London: Lawrence Erlbaum Associates.

Dörnyei, Z. \& Ryan, S. (2015). The Psychology of the Language Learner Revisited. New York: Routledge.

Ellis, R. (2008). The Study of Second Language Acquisition. (2nd Edition). Oxford: Oxford University Press.

Griffiths, C. (2013). The Strategy Factor in Successful Language Learning. Bristol, U.K.: Multilingual Matters.

Griffiths, C. (2018). The Strategy Factor in Successful Language Learning: The Tornado Effect. New York: Multilingual Matters.

Guthrie, J. T., Wigfield, A. \& VonSecker, C. (2000). Effects of integrated instruction on motivation and strategy use in reading. Journal of Educational Psychology. 92(2). 331-341.

Harrish, S. (2014). Social strategy use and language learning contexts: A case study of Malayalee undergraduate students in India. System. 43, 64-73.

Haskell, R. E. (2001). Transfer of Learning: Cognition, instruction, and reasoning. San Diego, CA: Academic Press.

Hung, B. P. (2019). A cognitive linguistic approach to teaching English Idioms to EFL students: Experimental results. 3L: Language, Linguistics, Literature. 25(2), 133-126.

James, M. A. (2010). An investigation of learning transfer in English for general academic purposes writing instruction. Journal of Second Language Writing, 19, 183-206.

Jantawong, L., Yuso, P. \& Nilwichien, S. (2018). Language learning strategies employed by high and low language proficiency university students in a Thai Context. Journal of Southern Technology. 11(1), 111.

Kitjaroonchai, N. \& Kitjaroonchai, T. (2012). Motivation toward English language learning of Thai students majoring in English at Asia-Pacific International University. Catalyst. 7(1), 21-38.

Kotesombat, N. (2003). A case study of usage in English language learning strategies. Master of Art Thesis in Applied Linguistics, Graduate School, Mahidol University.

Krashen, S. (2011). Academic proficiency (language and content) and the role of strategies. TESOL Journal. 2(4), 381-393.

Liu, J. (2010). Language learning strategies and its training model. International Education Studies. 3(3), $100-$ 104.

Lynch, D. J. (2010). Motivational beliefs and learning strategies as predictors of academic performance in college Physics. College Student Journal. 44(4), 1-8.

Magno, J. M. \& Maxilom, R. M. (2016). Japanese learners' reading strategies and oral interlanguages. International Journal of Education, Culture and Society. 1(3), 86-94.

Mochizuki, A. (2016). Language learning strategies used by Japanese university students. RELC Journal. 30(2), 101-113.

Oxford, R. L. (1996). Language Learning Strategies around the World: Cross-cultural Perspectives. Manoa: University of Hawaii Press.

Oxford, R. L. (2003). Language learning styles and strategies: concepts and relationships. International Review of Applied Linguistics in Language Teaching, 41 (4), 271-278.

Oxford, R. L. (2011). Teaching and researching language learning strategies. London: Pearson.

Oxford, R. L., Rubin, J., Chamot, A., schramm, K., Lavine, R., Gunning, P. \& Nel, C. (2014). The learning strategy prism: Perspectives of learning strategy experts. System. 43, 30-49.

Oxford, R. L. (2017). Teaching and Researching Language Learning Strategies: Self-regulation in context. (2nd Edition). New York: Routledge.

Pathomchaiwat, P. (2013). English language learning strategies used by university students: A case study of English and business English major at Suan Sunandha Rajabhat in Bangkok. World Academy of 
Science, Engineering and Technology International Journal of Industrial and Systems Engineering. 7(5), 1157-1161.

Phonhan, P. (2016). Language learning strategies of EFL education students: A case study of Thai undergraduate students. Silpakorn University Journal of Social Sciences, Humanities, and Arts. 16(2), 115-135.

Singh, K. (2011). Study of achievement motivation in relation to academic achievement of students. International Journal of Educational Planning and Administration. 1(2), 161-171.

Suliman, A., Yunus, M. M. \& Nor, M. Y. (2019). Scrutinising the preferences in literature approaches and activities: From the lenses of ESL teachers. 3L: Language, Linguistics, Literature: The Southeast Asian Journal of English Language Studies, 25(2), 38-48.

Tuckman, B. W. \& Kennedy, G. J. (2011). Teaching learning strategies to increase success of first term college students. Journal of Experimental Education. 79(4), 478-504.

Weinstein, C. E. \& Palmer, D. R. (2002). Learning and Study Strategies Inventory (LASSI): User's manual. Clearwater, FL: H \& H Publishing.

Wong, L. \& Nunan, D. (2011). The learning styles and strategies of effective language learners. System. 39(2), 144-163. 